\title{
The Effect of Financial Literacy, Financial Technology, and Digital Promotion on Online Purchasing Decisions in the Covid-19 Pandemic Era
}

\author{
Susanti ${ }^{1, *}$ Han T. Hardini ${ }^{1,}$ Moh. D. Bahtiar ${ }^{1}$ \\ ${ }^{1}$ Universitas Negeri Surabaya, Faculty of Economy, Surabaya, Indonesia \\ "Corresponding author: susanti@unesa.ac.id
}

\begin{abstract}
Covid-19 pandemic has a broad impact on the habits of the community, especially for students and housewives in fulfilling their needs. Government recommendations to comply with health protocols with social restrictions cause them to prefer shopping online. Some factors that are thought to influence online shopping decisions are financial literacy, financial technology, and digital promotion. This study aims to examine the effect of financial literacy, financial technology, and digital promotion on online purchasing decisions in the co-19 era pandemic. This type of research is quantitative research. The research population is the online shopping user community in Surabaya, aged between 20-40 years. The research sample in this study were 110 people consisting of students and housewives. Data collection techniques in the form of questionnaires and tests. Data analysis techniques using multiple regression. The results showed that financial literacy has a partial effect on online purchasing decisions as evidenced by a sign value of $0.001<0.05$, financial technology has a partial effect on online purchase decisions as evidenced by a sign value of $0.013<0.05$, digital promotions have a partial effect on online purchases as evidenced by the sign value. $0.00<0.05$. Simultaneously, financial literacy, financial technology, and digital promotion influence online purchasing decisions as evidenced by a sign value of $0.00<0.05$.
\end{abstract}

Keywords: Financial literacy, Financial technology, Digital promotion, Online purchasing

\section{INTRODUCTION}

Countries in the world are currently faced with various problems caused by the Covid-19 pandemic. The increase in positive cases that occurs from day to day causes many losses to various sectors in Indonesia. One of them is the economic sector. On April 6, 2020, the Minister of Finance of the Republic of Indonesia, Sri Mulyani even said that the crisis caused by the current corona virus is much more complex than the 1997-1998 and 2008-2009 crises [1]. To deal with the greater impact of the COVID 19 pandemic, the government advises all Indonesian citizens not to become infected in the spread of the COVID 19 virus to follow health protocols. Among them are carrying out social distancing on a large scale, maintaining health in accordance with WHO recommendations by maintaining a distance of 1 meter from other people, using masks, washing hands with hand sanitizer/ soap and maintaining cleanliness.
During the COVID19 pandemic, data and artificial intelligence (AI) company Analytic Data Advertising (ADA) noted a surge in the use of government online shopping applications during the implementation of physical distancing to prevent the spread of the Covid19 virus pandemic. In a press release, Monday (13/4), ADA noted that the use of online shopping applications jumped by $300 \%$ when social distancing was implemented, in order to tackle the spread of the corona virus or Covid-19 [2].

The development of internet technology makes it easier for people to shop, especially during this pandemic. Consumers no longer need to come to shopping centers or shops to shop, but simply by using gadgets, consumers can shop by visiting various websites which are often referred to as online shopping. Online shopping makes it easier for us to shop without wasting time and effort because this convenience makes online shopping even more desirable. Through online buyers can see the various products offered through the 
web that are promoted by the seller. Online shopping allows buyers and sellers not to meet face to face, so this allows sellers to have the opportunity to get buyers from abroad.

Online purchasing is the activity of purchasing products (both goods and services) via the internet [3]. Online shopping activities include Business to Business (B2B) and Business to Consumers (B2C) activities. Online shopping here is a retail transaction with individual buyers, so online shopping here is a purchasing decision made by individuals online. One of the benefits of online shopping is that prospective buyers can preview the (product) they will buy through the web offered by the seller. This activity is often called searching

Purchasing decisions are the actions or behavior of a person in making a decision to choose a product both in terms of the type and quantity of the product itself [4]. The decision process itself consists of at least five stages including recognition of needs, seeking information, evaluating alternatives, determining purchases and purchasing behavior which is generally a satisfaction with the choice of decisions taken.

There are several factors that are thought to have influenced online purchasing decisions during the Covid 19 pandemic, including financial literacy. Sufficient literacy will have a positive influence on a person's financial behavior, such as managing or allocating finances appropriately [5]. A person's financial literacy that can be measured from indicators: literacy about general knowledge of finance, income, savings, loans and investments can affect a person's behavior in spending his finances [6]. During the Covid 19 pandemic, online purchases were a solution for the community to meet their needs because of their fear of the impact of the Covid 19 virus outbreak.

The behavior of online purchasing decisions can also be influenced by financial technology. According to Bank Indonesia Regulation Number 19/12 / PBI / 2017 [7], FinTech is the use of financial system technology that produces new products, services, technology and / or business models and can have an impact on monetary stability, financial system stability, efficiency, smooth operation, security and reliability of the payment system. Fintech is an innovation that provides convenience and comfort for people in the financial sector, because people can make transactions only with smartphones and the internet. The presence of fintech has had a positive impact on improving the economy as it continues to grow in volume and value of shopping transactions.

Online promotion factors are also thought to have influenced online purchasing decisions during the Covid pandemic 19. Research on the Effect of Online Promotion and Price Perceptions on Purchasing Decisions (Survey on Aryka Shop Customers in Malang City), shows that both partially and simultaneously online promotion and price perception has a positive influence on purchasing decisions [8]. Research on the Effect of My Kitchen Helper Online Promotion on Existing Consumer Online Purchase Decisions, shows that online promotion has a positive influence on online purchasing decisions [9].

Currently online purchasing is the most interesting issue to study as one of the behaviors of the community because it is part of the impact of Covid 19. So it is necessary to conduct research on the behavior of people's online purchasing decisions with the factors that influence it. So that the formulation of the problem in this study are: (1) Is there any influence of financial literacy on online purchasing decisions during the Covid 19 pandemic?, (2) Is there any influence of digital financial technology on online purchasing decisions during the Covid 19 pandemic?, (3) Is there any influence of digital promotions on online purchasing decisions during the Covid 19 pandemic?, (4) Is there a simultaneous influence between financial literacy, digital financial technology, and digital promotion on online purchasing decisions during the Covid 19 pandemic?

\section{METHOD}

The method in this research is a quantitative method. The sample in this study were 110 respondents. The respondents were students at the State University of Surabaya and housewives who made purchases online. Respondents who make online purchases consist of students of the Faculty of Economics, and non-students (housewives, workers, employees, and others). The following is a table showing the number of respondent data: 
Table 1. Characteristics of research respondents

\begin{tabular}{|c|c|c|}
\hline No & Respondents & Total \\
\hline 1 & Student & 85 \\
2 & Non student & 25 \\
\hline & Total respondents & 110 \\
\hline
\end{tabular}

Based on table 1, it is explained that the respondents who filled out the online questionnaire were 130 people, but because there were 20 respondents who did not fill in fully, then in this study sample only those who met the requirements were taken, namely 110 people.

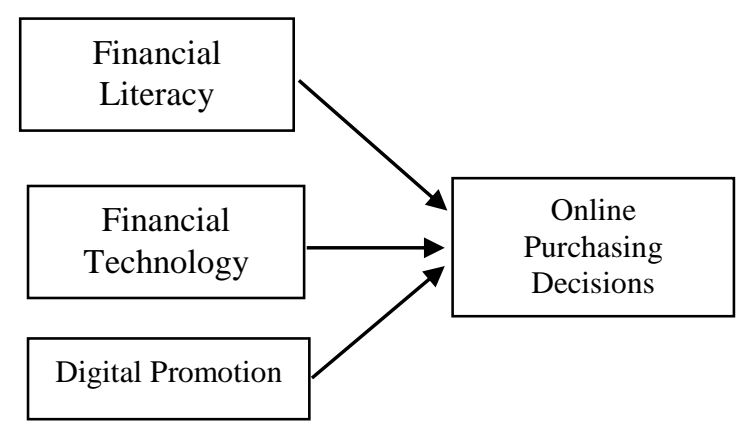

Figure 1 Relationship between research variables

The operational definition of variables in the financial literacy variable is the respondents' personal knowledge of general knowledge of finance, income, savings, loans, and investments. The research instrument for the financial literacy variable was a test of respondents' understanding of financial knowledge, with a total of 25 multiple choice questions. Instruments for financial literacy, financial technology and digital promotion variables use 5 answer options on a Likert scale. The Likert scale consists of $1=$ strongly disagree, $2=$ disagree, $3=$ sufficient, $4=$ agree, and $5=$ strongly agree.

The data collection technique uses an online questionnaire about the variables of financial literacy (X1), financial technology (X2) and digital promotion (X3), as well as online purchasing decisions (Y). The data analysis technique used multiple regression. Multiple linear regression analysis is used to determine the effect of two or more independent variables on one dependent variable [10]. Based on Figure 1, the mathematical equation is as follows:
The relationship between research variables can be shown in the following figure:

$$
\mathrm{Y}=\mathrm{A}+\mathrm{B1FL}+\mathrm{B2FT}+\mathrm{B3DP}+e
$$

Information:

Y : Online Purchasing Decisions

A : Konstanta

ß1,ß2,ß3: Coefision Regression

FL : Financial Literacy

FT : Financial Technology

DP : Digital Promotion

e : Standar eror

\section{RESULTS AND DISCUSSION}

\subsection{Result}

The results of the descriptive analysis show that chacacteristics of research respondents consist of financial literacy level and online purchase respondent. Below is table 2 which shows the literacy level of the respondents. 
Table 2. Respondents' financial literacy level

\begin{tabular}{|c|c|c|}
\hline No. & Financial Literacy Level & Total \\
\hline 1 & Less & 48 \\
2 & Moderate & 52 \\
3 & High & 10 \\
\hline \multicolumn{2}{|c|}{ Total Respondent } & 110 \\
\hline
\end{tabular}

Based on table 2, it is explained that the literacy level of the respondents consists of low (48 respondents), medium (52 respondents) and high (10 respondents).
Meanwhile, the average consumption of online purchases that respondents have made in the past 1 month is classified as follows:

Table 3. Online purchases made for 1 month

\begin{tabular}{|c|c|c|}
\hline No. & Purchase Type & Prosentase \\
\hline 1 & Food & $75 \%$ \\
2 & Household appliances & $10 \%$ \\
3 & Women's clothing, headscarves and accessories & $20 \%$ \\
& Other & $5 \%$ \\
\hline & & $100 \%$ \\
\hline
\end{tabular}

Based on table 3, it is explained that of the 120 respondents who made online purchases for consumption in the form of food as much as $75 \%$. The rest is buying household utensils (as much as 10\%) such as cooking utensils, toiletries and others. Housewives also like to buy clothes, headscarves and women's 3.1.1. Classic Assumption Test

Before the regression data analysis test is carried out, the classical assumption test is carried out, namely the normality and multicollinearity test as follows: accessories online (20\%), and the rest is other needs as much as $5 \%$.

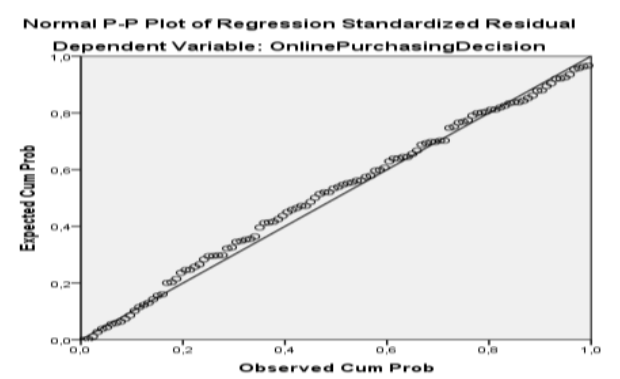

Figure 2 P-Plot

Based on Figure 2, the P-Plot shows that the points are approaching a straight line so that it can be concluded that the data is normal. So that it meets the normality test. Meanwhile, to find out that the data is free of multicollinearity, it can be shown by the results of the SPSS test as follows: 
Table 4. Multikolinearitas Data (Coefficients $\left.{ }^{\mathrm{a}}\right)$

\begin{tabular}{|c|c|c|c|c|c|c|c|c|}
\hline \multirow[b]{2}{*}{ Model } & & \multicolumn{2}{|c|}{ Unstandardized Coefficients } & \multirow{2}{*}{$\begin{array}{c}\begin{array}{c}\text { Standardized } \\
\text { Coefficients }\end{array} \\
\text { Beta } \\
\end{array}$} & \multirow[b]{2}{*}{$t$} & \multirow[b]{2}{*}{ Sig. } & \multicolumn{2}{|c|}{ Collinearity Statistics } \\
\hline & & $B$ & Std. Error & & & & Tolerance & $\mathrm{VIF}$ \\
\hline \multirow[t]{4}{*}{1} & (Constant) & 28,988 & 4,187 & & 6,924 & .000 & & \\
\hline & LiterasiKeuangan & .171 &, 047 &, 290 & 3,612 &, 000 &, 833 & 1,201 \\
\hline & FinancialTecnology & .116 &, 048 & 197 & 2,448 & .016 &, 831 & 1,203 \\
\hline & PromotionDigital & .477 & .088 & .413 & 5,400 & .000 & .917 & 1,091 \\
\hline
\end{tabular}

a. Dependent Variable: OnlinePurchasingDecision

Based on table 4, it is found that the VIF value is less than 10 , so it can be concluded that the data is free of multicollinearity.

The $\mathrm{R}$ test is used to determine how much the independent variable contributes simultaneously to the dependent variable. The following is a model summary table showing the $\mathrm{R}$ (coefficient of determination) of a model.

\subsubsection{Test-R}

Based on the results of SPSS version 22 above, the data shows that the Adjusted R Square value is 0.416. This means that the online purchasing decision variable is jointly influenced by the variables of financial literacy, financial technology, and digital promotion by $41.6 \%$.

Table 5. Model summary

\begin{tabular}{|l|l|r|r|r|r|}
\hline Model & $\mathrm{R}$ & R Square & $\begin{array}{c}\text { Adjusted R } \\
\text { Square }\end{array}$ & $\begin{array}{c}\text { Std. Error of } \\
\text { the Estimate }\end{array}$ & $\begin{array}{c}\text { Durbin- } \\
\text { Watson }\end{array}$ \\
\hline 1 &, $657^{\mathrm{a}}$ &, 432 & .416 & 4,121 & 1,833 \\
\hline
\end{tabular}

a. Predictors: (Constant), PromotionDigital, Literasikeuangan, FinancialTecnology

b. Dependent Variable: OnlinePurchasingDecision

3.1.3 Test $-t$

Table 6. T-test (Coefficients ${ }^{\mathrm{a}}$ )

\begin{tabular}{|ll|r|r|r|r|r|}
\hline \multirow{2}{*}{ Model } & \multicolumn{2}{|c|}{ Unstandardized Coefficients } & $\begin{array}{c}\text { Standardized } \\
\text { Coefficients }\end{array}$ & & \\
\cline { 2 - 4 } & & \multicolumn{1}{|c|}{$\mathrm{B}$} & \multicolumn{1}{|c|}{ Std. Error } & \multicolumn{1}{c|}{ Beta } & \multicolumn{1}{c|}{ Sig. } \\
\hline & (Constant) & 29,059 & 4,163 & & 6,981 &, 000 \\
& LiterasiKeuangan &, 165 &, 048 &, 280 & 3,448 &, 001 \\
& FinancialTecnology &, 121 &, 048 &, 205 & 2,520 &, 013 \\
& PromotionDigital &, 477 &, 088 &, 413 & 5,418 &, 000 \\
\hline
\end{tabular}

a. Dependent Variable: OnlinePurchasingDecision

Table 5 is used to test the influence hypothesis between variables. Based on this data, it can be explained as follows:

Ha 1: There is an influence between financial literacy on online purchasing decisions during the Covid 19 pandemic

Based on the coefficient table above, the t-value for the variable is 3.448 , and the significance value is 0.001 $<0.05$, so that Ha1 is accepted. So it can be concluded that there is an influence between financial literacy variables on online purchasing decisions during the Covid 19 pandemic.
The $t$ test is used to answer the influence between the research variables. Based on the results of the SPSS test, the $t$ test data is obtained in table 5 below:
Ha 2: There is an influence digital financial technology on online purchasing decisions during the Covid 19 pandemic.

Based on the coefficient table above, the t-value for the financial technology variable on online purchasing decisions during the Covid 19 pandemic is 2.520, and a significance value of $0.013<0.05$, so $\mathrm{Ha} 2$ is accepted. So it can be concluded that there is an influence between financial technology financial variables on online purchasing decisions during the Covid 19 pandemic.

Ha 3: There is an influence digital promotions on online purchasing decisions during the Covid 19 pandemic. 
Based on the coefficient table above, the t-value for the digital promotion variable on online purchasing decisions during the Covid19 pandemic is 5.418, and a significance value of $0.00<0.05$, so $\mathrm{Ha} 3$ is accepted. So it can be concluded that there is an influence between financial technology financial variables on online purchasing decisions during the Covid 19 pandemic.

\subsubsection{Test $F$}

The $\mathrm{F}$ test serves to test the simultaneous influence between research variables. The criteria for acceptance of $\mathrm{Ha}$ is if $\mathrm{F}$ count $>\mathrm{F}$ table, or it can be seen from the table sig $<0.05$. The results of the $\mathrm{F}$ test can be shown in the following ANOVA table:

Table 7. Anova

\begin{tabular}{|c|c|c|c|c|c|c|}
\hline Model & & $\begin{array}{c}\text { Sum of } \\
\text { Squares }\end{array}$ & df & Mean Square & $\mathrm{F}$ & Sig. \\
\hline \multirow[t]{3}{*}{1} & Regression & 1376,215 & 3 & 458,738 & 27,099 & $.000^{b}$ \\
\hline & Residual & 1794,376 & 106 & 16,928 & & \\
\hline & Total & 3170,591 & 109 & & & \\
\hline
\end{tabular}

b. Predictors: (Constant), PromotionDigital, LiterasiKeuangan, FinancialTecnology

Ha 4: There is a simultaneous influence between financial literacy, financial technology, and digital promotion on online purchasing decisions during the Covid 19 pandemic. In table 6 above the significance value of 0.00 $<0.05$, then Ha 4 is accepted. So it can be concluded that there is a simultaneous influence between financial literacy, financial technology, and digital promotion on online purchasing decisions during the Covid 19 pandemic.

\subsection{Discussion}

\subsubsection{Financial Literacy Affects Online Purchasing Decisions during the Covid19 Pandemic}

The regression results show that the significance value between financial literacy variables on online purchasing decisions is a sign value of $0.00<0.05$. This shows that there is an influence between financial literacy on online purchasing decisions.

Having financial literacy is very vital to have a prosperous life. With proper financial management which is certainly supported by good financial literacy, the standard of living is expected to increase, this applies to every income, because no matter how high a person's income level, without proper management, finance will be difficult to achieve [11]. Without having knowledge and skills in finance, the possibility of making mistakes in managing financial resources will be even greater and prosperity will be difficult to achieve. Financial literacy in this study is measured by indicator (1). General knowledge about finance, (2). Income, (3). Savings, (4). Loans, and (5) investment, while online purchasing decisions are measured by the following indicators: (1). fast in deciding the purchase (2). believe that the decisions taken are correct. (3). Convenience in transactions (4). Confidence in buying online.

Based on the research findings, respondents who are interested in online purchases feel confident about the decision to buy online because they have financial knowledge. Financial knowledge includes how to use money to behave financially well as evidenced by the purchase decision. However, not all respondents decide to buy because they are for their own needs, but because of their desire to be interested in the products offered online. Of course, if they do not have financial knowledge, the respondent will buy products continuously, causing financial difficulties in the future.

The results of this study are in accordance with previous research, namely Anisa [12] who explained that financial literacy has a negative effect on impulsive product purchase decisions online in generation $\mathrm{Y}$. The results of Lam's research [13] also explained that there is a significant negative between financial literacy and online shopping problems.

\subsubsection{Technology Finance for Online Purchasing Decisions during the Covid19 Pandemic}

The regression results show that the significance value between the variables of digital financial technology on online purchasing decisions is a sig value of $0.00<0.05$. This shows that there is an influence between financial digital technology on online purchasing decisions.

Along with changes in digital technology, many digital financial products have emerged. Therefore, many respondents are technologically literate. In this case, the respondents are students and housewives who 
currently have more sophisticated mobile phone facilities in which financial technology features are available, making it easier to buy online. According to them, making purchases online is much easier and faster than having to go out of the house which is timeconsuming, costly and can catch the Covid 19 virus.

This is in accordance with research during the Covid 19 pandemic, that there is a trend of significant changes in consumer behavior. As many as 50 percent of Indonesians have begun to reduce their activities outside the home and 30 percent of them admit to planning to shop online more often. [14]. The desire to shop online is expected to continue to increase along with compliance with Large-Scale Social Restrictions (PSBB) and personal awareness to avoid crowds. In addition, consumers also tend to shop for basic necessities in large quantities, which have the potential for price spikes due to dwindling supply. [14] The Director of Kredivo saw that during the Covid-19 pandemic, consumers were increasingly encouraged to shop online and use financial technology (fintech) in order to be able to transact cashless because of the awareness to implement physical distancing.

\subsubsection{Digital Promotion of Online Purchasing Decisions during the Covid19 Pandemic}

The regression results show that the significance value between digital promotion variables on online purchase decisions is a sig value of $0.00<0.05$. This shows that there is an influence between digital promotions on online purchasing decisions.

With the online promotion, it is easy for respondents to obtain information related to the services offered by online service businesses. As a result of online promotions during this pandemic, online service businesses have benefited a lot because they have experienced an increase in the number of consumers compared to traditional promotions. Respondents to online purchases assess that online promotions can attract attention so that they increase their interest and desire to find out more about the various promotional packages offered, and in the end the community decides to use online services during the Covid 19 pandemic. The research findings reinforce the results of previous research conducted by Jamaludin et al. [8] and Gunawan [9], who concluded that online promotion has an effect on online purchasing decisions

\subsubsection{Financial Literacy, Financial Technology and Digital Promotion Have a Simultaneous Effect on Online Purchasing Decisions during the Covid 19 Pandemic}

Based on the results of data analysis, it is concluded that there is a simultaneous influence between financial literacy, financial technology, and digital promotion on online purchases during the Covid 19 pandemic. So it can be concluded that the relationship between variables in the study sample can apply to the population in this study.

\section{CONCLUSION}

Based on the results of the study, it can be concluded that there is an influence between financial literacy, financial technology and digital promotion on online purchasing decisions during the Covid-19 pandemic. The implication of this study is that the impact of Covid 19 has influenced people to protect themselves by meeting household needs by making purchases by online. Therefore, there is a need for education about financial literacy and digital finance for online shopping users so that they don't spend too much money on purchases, especially online purchases.This is also a protection for spending money on priority needs, not because of the desire to avoid difficulties in the future. In addition, with education about digital finance, it will reduce wrong use and reduce the impact of crime from others due to ignorance of the procedures for using the digital financial system.

\section{ACKNOWLEDGMENTS}

We would like to thank the lecturers and students at the Faculty of Economics, State University of Surabaya who have helped and provided advice and support for this research.

\section{REFERENCES}

[1] Victoria, Agatha Olivia. 2020. Sri Mulyani Sebut Covid-19 Lebih Kompleks dari Krisis 1998 dan 2008. https://katadata.co.id/berita/2020/04/07/srimulyani-sebut-covid-19-lebih-kompleks-darikrisis-1998-dan-2008.

[2] Burhan, Fahmi Ahmad. 2020. Dampak Pandemi Covid 19 Pada Penggunaan Aplikasi belanja 
Melonjak $300 \quad$ Persen. https://katadata.co.id/agungjatmiko/digital/5e9a41c 9cb3c5/dampak-pandemi-covid-19-penggunaanaplikasi-belanja-melonjak-300

[3] Katawetawaraks, C. \& Cheng, L. W. (2011). Online shopper behavior: Influences of online shopping decision. Asian Journal of Business Research, 1 (2), 66-74.

[4] Kotler, P., dan Keller, K.L. 2012. Marketing Management. New Jersey: Pearson Education, Inc.

[5] Robb, C. A., \& Woodyard, A. S. 2011. finanacial knowledge and best practice behaviour. Journal of financial Counseling and planning Volume 22 Issue 1.

[6] Chen H and Volpe R P 1998 An Analysis of Personal Financial Literacy Among College Students Financ. Serv. Rev. 7 107-28

[7] Bank Indonesia. (2017). Peraturan Bank Indonesia Nomor 19/12/PBI/2017 tentang Penyelenggaraan Teknologi Finansial. Jakarta: Bank Indonesia

[8] Jamaludin, A., Arifin, Z., dan Hidayat, K. 2015. Pengaruh Promosi Online dan Persepsi Harga terhadap Keputusan Pembelian (Survei pada Pelanggan Aryka Shop di Kota Malang). Jurnal Administrasi Bisnis (JAB), 21(1): 1- 8.

[9] Gunawan, T.M. 2014. Pengaruh Promosi Online My Kitchen Helper terhadap Keputusan Pembelian
Online Konsumen Existing. Diakses dari http:// library.unpar.ac.id/index.php?p=show_detail\&id=1 95234.

[10] Ghozali, Imam. 2013. Analisis Multivariate Dengan SPSS . Semarang: BP UNDIP

[11] Awais, M., Laber,M.F., Rasheed, N., Khursheed, A. 2016. Impact of Financial Literacy and Investment Experience on Risk Tolerance and Investment Decision : Empirical Evidence from Pakistan. International Journal of Economics and Financial Issues. Vol.6, 73-79

[12] Anisa, Nur, Ady Soejoto dan Harti. 2017. Financial Literacy, Product Knowledge and Psychological Factors on Impulsive Buying in $\mathrm{Y}$ Generation. Journal of International Business and Economics December 2017, Vol. 5, No. 2, pp. 63-68 ISSN: 2374-2208(Print), 23742194(Online).10.15640/jibe.v5n2a7.

[13] Lam, Lawrence T, dan Lam, Merry K. 2017. The association betweenfinancial literacy and Problematic InternetShopping in a multinational sample. Adictive Behavior Report 6 (2017) 123 127. https://doi.org/10.1016/j.abrep.2017.10.00

[14]Lavi, Gloria Fransisca Katharina. 2020. Fintech Mesti Dorong Edukasi dan Proteksi Belanja Online. https://finansial.bisnis.com/read/20200418/563/122 8954/fintech-mesti-dorong-edukasi-dan-proteksibelanja-online 